\title{
A CINEMATIC NARRATION OF THE GREAT DEPRESSION: RECALLING JOHN FORD'S THE GRAPES OF WRATH
}

\author{
Levent YILMAZOK \\ Mimar Sinan Fine Arts University, Turkey \\ leventyilmazok@hotmail.com
}

\begin{abstract}
John Steinbeck's novel The Grapes of Wrath, published in 1939, depicts the poverty of 1930s America during the "Great Depression" through the tragedy of the Joad family, who lost their home and land in Oklahoma and have to drive to California in the hope of finding employment and plenty like many other farmers. The novel was adapted for the cinema the same year and directed by John Ford. Proving welcome in cinema circles and taking its place as a master work in film history, it was one of the few films with radical political connotations hitherto produced by Hollywood.

Nevertheless, this cinematic version of the Great Depression narrative has not escaped criticisms, which have been aimed chiefly at aspects of its content that diverge from its parent work. Compared with the novel, the film has been considered more conservative and optimistic, on the grounds that, although the novel emphasizes the class conflict and portrays the Joads as only one of the many suffering families, the film exerts a redundant focus on the family and commends family values: divergences considered to be supported by the visual style of the film. In this article, while recalling Ford's The Grapes of Wrath, I revisit the above-mentioned criticisms and reassess them in relation to the parenting novel. In doing so, this article also aims to evoke the ongoing economic recession that influences the masses all over the world and the recurrent, unchanging and inevitable outcomes that such crises of capitalism bring for its victims.
\end{abstract}

Keywords: The Grapes of Wrath, John Ford, film, visual style, adaptation.

\section{İKTISADİ KRIZZIN SINEMASAL ANLATIMI: JOHN FORD'UN GAZAP ÜZÜMLERI FILMİ}

\begin{abstract}
ÖZET
John Steinbeck'in 1939 yılında yayınlanan Gazap Üzümleri romanı, "büyük buhran” olarak bilinen ve 1930'lar boyunca süren iktisadi krizin Amerika Birleşik Devletleri'ndeki etkilerini ve bu krizin tetiklediği yoksulluğun boyutlarını göstermekte, bunu Oklahoma'daki evlerini ve arazilerini kaybedip diğer binlerce çiftçi ailesi gibi iş bulma ve zenginleşme umuduyla Kaliforniya'ya göç etmek zorunda kalan Joad ailesinin trajedisi üzerinden yapmaktadır. Roman yayınlandığı yıl sinemaya uyarlanmıştır. Sinema çevrelerinde büyük bir beğeniyle karşılanan ve Hollywood'un o güne kadar ürettiği en radikal siyasi mesajlarla örülü filmlerden biri olan bu uyarlama sinema tarihinin başyapıtları arasındaki yerini almıştır. Ancak, iktisadi kriz anlatısının bu sinema versiyonu yapıldığından bu yana geçen yıllar içinde eleştirilere konu olmaktan kurtulamamıştır. Eleştiriler özellikle filmin kaynak romandan farklılaşan içeriğine yönelmiş, romanla karşılaştıııldığında film daha muhafazakar ve iyimser olarak değerlendirilmiştir. Kaynak romanın sınıf çatışmasına vurgu yapmasına ve Joad ailesini krizin etkilediği ailelerden yalnızca biri olarak resmetmesine karşın filmin aileyi ve aile değerlerini öne çıkarması muhafazakarlık eleştirilerinin başlıca dayanaklarından biri olagelmiştir. Bu farklılaşmanın filmin görsel biçimince de desteklendiği öne sürülmüştür. Bu makalede Ford'un Gazap Üzümleri filmine ilişkin sözü edilen eleştiriler kaynak romanla da bağlantılandırılarak ele alınıp değerlendirilirken, dünya genelinde sürmekte olan iktisadi krize ve kapitalizmin bu tür krizlerinin değişmeyen ve kaçınılmaz sonuçlarına dikkat çekilmektedir.
\end{abstract}

Anahtar Kelimeler: Gazap Üzümleri, John Ford, film, görsel biçim, uyarlama. 


\section{A Cinematic Narration of the Great Depression: Recalling John Ford's The Grapes of Wrath}

John Steinbeck's novel The Grapes of Wrath, published in 1939, depicts the poverty of 1930s America during the "Great Depression" through the tragedy of the Joad family, who lost their home and land in Oklahoma and have to drive to California in the hope of finding employment and plenty like many other farmers. The novel was adapted for the cinema the same year (released in March 1940) and directed by John Ford. Proving welcome in cinema circles and taking its place as a master work in film history, it was one of the few films with radical political connotations hitherto produced by Hollywood.

Nevertheless, this cinematic version of the Great Depression narrative has not escaped criticisms, which have been aimed chiefly at aspects of its content that diverge from its parent work. Compared with the novel, the film has been considered more conservative and optimistic, on the grounds that, although the novel emphasizes the class conflict and portrays the Joads as only one of the many suffering families, the film exerts a redundant focus on the family and commends family values: divergences considered to be supported by the visual style of the film. Vivian Sobchack, for instance, drew attention to the dominant framing - that omits wide-open spaces - and the darkness, which both serve to isolate and abstract the family from the larger context.

In this article, while recalling The Grapes of Wrath as a cinematic narration of the Great Depression, I will revisit the above-mentioned criticisms and reassess them in relation to the parenting novel. First, I will provide the summary of the novel to give a general insight about the introduced topic. This will be followed by the criticisms directed at the adapted film and its director. Then, the divergences in terms of both content and visual style will be put forth in more detail. Finally, the arguments and counter-arguments around this adaptation and my consideration of the film will be epitomized.

\section{The Novel}

John Steinbeck composed The Grapes of Wrath between late May and late October 1938. He aimed this novel to be "a truly American book" and accomplished that besides making it the greatest of his 17 novels (DeMott, 2000). It was published in April 1939 and won the 1940 Pulitzer Prize. There has not been a consensus on the novel's quality though. Although the novel has been "praised by the left as a triumph of proletarian writing" (DeMott, 2000, p.xxxvi), it could not escape criticisms. Academic scholars attacked the book as "sentimental, unconvincing, and inartistic"; school boards and libraries banned it for its "rebellious theme and frank language"; and the right-wing ministers, corporate farmers, and politicians denounced as "communist, immoral, degrading, warped, and untruthful" (DeMott, 2000, p.xxxvii). On the other hand, Franklin Roosevelt, who was the president of the United States of America during the Great Depression, which was depicted in the novel, and his wife Eleanor Roosevelt, defended the novel for its "power, integrity, and accuracy" (DeMott, 2000, p.xxxvi). Next, I will provide a general summary of this controversial book.

Tom Joad is paroled after completing four years of his 7-year sentence - because of homicide - in prison and takes the road for his home. What he finds back is the evacuated lands and houses by the tenants, including his family, who had been living there and cultivating the soil for at least a few generations. Because the system, that is, the tenants who are indebted to the banks pay their loan because of the revenue yielded by the agricultural products, does not work any more as to replace the men with tractors is declared to be the efficient way to increase the profits of the banks. Furthermore, adverse climate conditions decrease the fertility of the land. A bank is mentioned as a "monster," which has to make profit and grow continuously and which otherwise will die: "Men made it, but they can't control it" (Steinbeck, 2000, p.36).

Forced to leave their home in Sallisaw, Oklahoma, the Joad family decides to drive to "rich land" California where they hope to commence a new life, to start over: "But you can't start. Only a baby can start" (Steinbeck, 2000, p.91). The ads in the papers call them and thousands of other people to pick grapes, oranges, and peaches. Thus, the Joads sell all of the movable things in their house and buy a truck. The ex-preacher Casy, whom Tom came across to on his way home, joins them but their 
neighbor Muley refuses to leave. Thirteen people - Granma, Grampa, Ma, Pa, Uncle John, Tom, Al, Noah, Rosasharn, Connie (Rosasharn's husband), two kids (Ruthie and Winfield), and Casy - start their journey. It is a two-thousand-mile way to California via Highway 66, the main migrant road, "the road of flight." Not only the Joads but also more than 300,000 other dispossessed in 50,000 cars are over the road to the west: "It's like a whole country is movin"" (Steinbeck, 2000, p.180). That is a "gold rush" for the new poor of America.

However, those new poor are not welcome in their destinations. The farmers who turn into migrants throughout this journey draw hard reactions from the local people almost everywhere they go because the locals are scared of losing what they have, scared of those "outlanders," of those "foreigners" because they may take the country. The Joad family members are called "Okies" by the Californians like the other people who come from Oklahoma. Moreover, the migrants and the Joads are labeled as "hard-looking," having "no sense and no feeling," "dirty," "miserable," "ignorant," "degenerate," "sexual maniacs," "thieves," and even "not human beings":

... the owners hated them because the owners knew they were soft and the Okies strong, that they were fed and the Okies hungry... And in the towns, the storekeepers hated them because they had no money to spend... The town men, little bankers, hated Okies because there was nothing to gain from them... And the laboring people hated Okies because a hungry man must work, and if he must work, if he has to work, the wage payer automatically gives him less for his work; and then no one can get more. (Steinbeck, p.244)

For the offered jobs, the policy of the employers is to invite more candidates than needed so as to pay lesser wage by taking the advantage of the competition among the labor force to get the job. In case you do not agree to the low salary, thousands of candidates are waiting and ready to work. To borrow a term from Marxist critique of capitalist political economy, these unemployed candidates - as forming an overpopulation - are the reserve army of labor, the potential future employees, and it is almost impossible to get a steady work. The migrants who are conscious of the employers' policy and speak against that are labeled as troublemaker "reds": "A red is any son-of-a-bitch that wants thirty cents an hour when we're payin' twenty-five!" (Steinbeck, 2000, p.312). All those experiences change the migrants in time to a level of more consciousness:

The movement changed them; the highways, the camps along the road, the fear of hunger and the hunger itself, changed them. They were migrants. And the hostility changed them, welded them, united them - hostility that made the little towns group and arm as though to repel an invader, squads with pick handles, clerks and storekeepers with shotguns, guarding the world against their own people. (Steinbeck, 2000, p.295).

Experiencing the maltreatment of the cops in Hooverville camp and Tom's breaking parole for hitting a deputy, the Joads feel forced to go to the government camp, Weedpatch, where there are no cops, where folks elect their own cops, and where the official cops cannot come in and arrest someone without a warrant. That "nice and clean" camp is run by its residents who make their own laws. They organize dance night every Saturday, and a nurse visits the camp every week. The Joads stay here for one month but cannot find jobs and have to leave. The family members fall apart on the odyssey, one by one. The first loss is Grampa, who dies of stroke. His death is followed by Granma's. As Casy says, "Grampa didn't die tonight. He died the minute you took 'im off the place" (Steinbeck, 2000, p.152). Noah and Connie run out for their dreams, and Casy first goes to jail for taking on the responsibility when Tom breaks parole for hitting a deputy in Hooverville camp. Later, he is killed during a strike led by him, and Tom has to leave the family to escape for killing the man who killed Casy.

In epitome, the number of family members diminishes to half while they are transformed from patriarchy to matriarchy. The power passes from $\mathrm{Pa}$ to Ma during the journey. Their hope for a new life turns into despair. As Bluestone (1973) states, "the grapes which Grampa dreamed of are inaccessible, that the grapes of promise inevitably turn to grapes of wrath" (p.155). 
The novel is rich in direct political messages and connotations, especially in the interchapters, from proposing union and organization of the working class to the rules of capitalism, from providing information about the imperialist history of the U.S. to the criticisms of religious beliefs and to the negative portrayal of the cops. Tom Joad becomes conscious out of what he has experienced throughout their odyssey. This is clearly manifested in his speech:

...I'll be ever'where - wherever you look. Wherever they's a fight so hungry people can eat, I'll be there. Wherever they's a cop beatin' up a guy, I'll be there... I'll be in the way kids laugh when they're hungry an' they know supper's ready. An' when our folks eat the stuff they raise an' live in the houses they build — why, I'll be there. (Steinbeck, 2000, p.439)

The adaptation of this novel to the cinema and its director have been criticized many times for making it a conservative version of the book and for degrading the political harshness of the narrative. The next section will address such criticisms.

\section{Criticisms: Ford and the Film}

The film The Grapes of Wrath has been chiefly criticized for its conservative tone and treatment of the parenting novel in that the film is more romanticist and optimist and opts for a happy ending compared with the source book. It has been claimed that the film does not project a vision of future socialism but intonates a labor-oriented traditionalism (Cassano, 2008) and propagates the New Deal policies of President Roosevelt that was programmed to create jobs by the public sector in the 1930s to overcome the consequences of the depression. The insistence of the film is said to be on family cohesion and affinity for the land and human dignity while muting the political radicalism and minimizing the religious satire of the novel (Bluestone, 1973). Thus, it is claimed that the film has functioned to "sweeten Steinbeck's bitterness" (Gallagher, 1986, p.176).

John Ford's comment on the story and the film may have contributed to the validity of the abovementioned criticisms. Tavernier quotes Ford as "Before all else, it is the story of a family, the way it reacts, how it is shaken by a serious problem which overwhelms it. It is not a social film on this problem, it's a study of a family" (as cited in Gallagher, 1986, p.177). Nevertheless, it needs to be stressed that, although most of the later critics denounced the film's softening of Steinbeck's radicalism and acceptance of New Deal policies, it was welcomed by the critics for its strong political commentary when the film was screened (Sanderson, 1989). Besides, it should be noted that the only indicator for the acceptance of New Deal policies in the film that is not in the novel is the zoomed image - from long shot to close up - of the Farmworkers' Wheat Patch Camp (Department of Agriculture) signboard at the entrance door of the camp that is run by the government, where the Joads stay for a while. A viewer can hardly notice any other sign or image that propagates Roosevelt's New Deal policies.
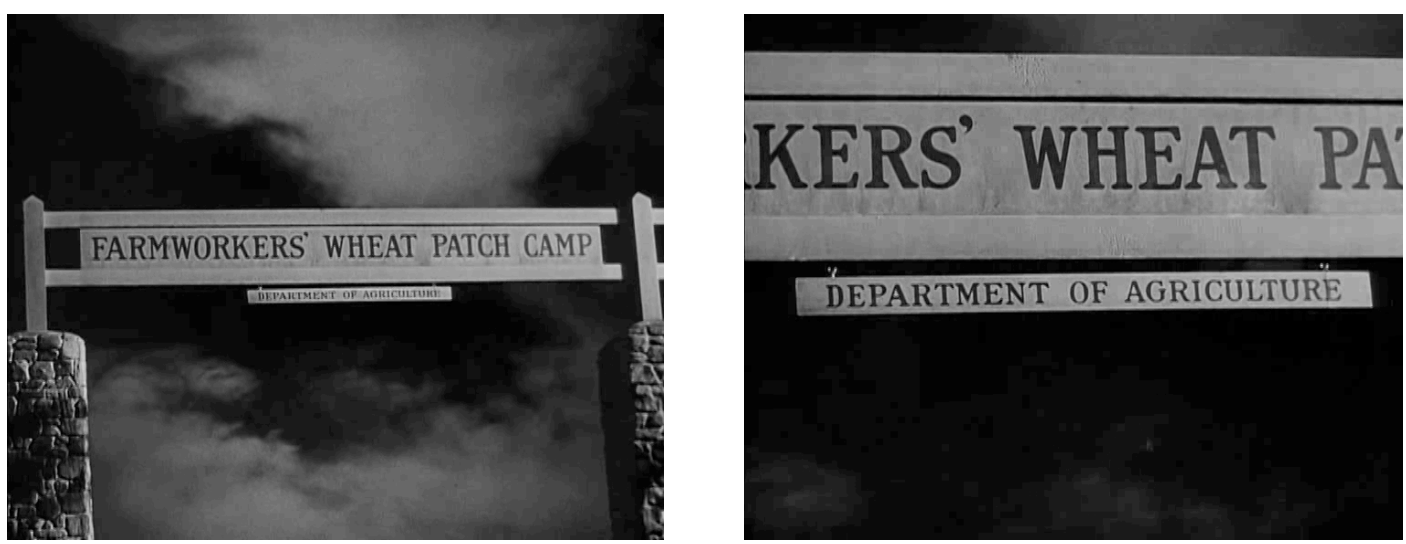

Figure 1: The zoomed image of Wheat Patch Camp from long shot to close-up. 
Not only the film, John Ford as an artist also had his share of criticisms. Vivian Sobchack (1979) generalized the highlights in Ford's films in comparison with Steinbeck's novels; she argued that, although Steinbeck's novels emphasize the importance of the present, harshness of reality, potential of radical politics, and need for social and political change, Ford's films emphasize the values of the past, soften the harsher aspects of historical reality with nostalgia, and are apolitical and atemporal in parallel to his aesthetic evocation of America that revolves around the harmony and established traditions of community. Ford has always been criticized for emphasizing political effects, not the causes and solutions (Gallagher, 1986).

Notwithstanding, McBride (as cited in Cassano, 2008, p.99) notes that Ford once defined himself as a "socialist democrat - always left" in a letter he wrote to his nephew who was fighting against fascism in Spain; he is rather known not as a politically biased artist but a patriot who accepts traditional American ideals such as justice, freedom, land, and family. This is verified by Ford's own words: "I come from a family of peasants. They came here and got an education. They served this country well. I love America. I am not political" (Sinclair, 1979, p.3). The family is important to him so much so that 37 of the 55 feature films he made during the sound era focus on or are related to family themes (Gallagher, 1986). Regarding The Grapes of Wrath, Ford explained in his interview with Peter Bogdanovich (1978) that he liked the story for it was similar to the migration of his family from Ireland.

It is also claimed that the film, as a final product, actually does not belong to Ford because there was many second unit work and studio operation in the editing phase (Sarris, 1976). However, Ford is known to be one of the few directors in Hollywood to enjoy the luxury of artistic freedom in the greatest sense, and a film credited with his name is finalized probably not without his consent. Another fact known about Ford is that he cuts the film in the camera and so leaves little room to the editor to play. Andrew Sinclair (1979), referring to Fred Zinnemann, informs that the final product is Ford's work: “... Ford fought Zanuck tooth and nail to keep in all he had shot, and he won his battle. As Fred Zinnemann acknowledged later about this episode, 'We owe the director's first cut to John Ford"' (p.99). On the other hand, Andrew Sarris (1976) argues that some changes were made - with an agreement by Ford, Zanuck, and the scriptwriter Nunnally Johnson - to enable the audience to identify with the sufferings of the characters. These were partly making the characters active rather than passive, partly stressing their coherence as a family but not as a class, and partly offering the Ma Joad's final speech (Sarris): "Rich fellas come up, and they die, and their kids ain't no good and they die out. But we keep coming. We are the people that live. They can't wipe us out. They can't lick us. We'll go on forever, Pa, cos we're the people" (Ford). Notwithstanding all the efforts made to soften the radical political tone of the novel, the creators of the film could not escape from the savage attacks by right wingers (Gallagher, 1986). Therefore, the film as an adaptation of a novel that includes political messages could satisfy neither left nor right.

Instead of stressing the relatively conservative tone of the film compared with the novel and speculating around actually the owner of the released product, one should rather notice the social climate - intolerant attitudes by the authorities against opponent voices all over the world - of the period and of Hollywood, I argue. In this context, the written and unwritten censorship codes and the restrictions of the studio system certainly had influence on the filmmaking practices. Moreover, possible negative reactions that might come from the locals to the filming of this radical novel forced Darryl Zanuck, the producer of the film, to announce it with a different title, Highway 66, for the shootings in Oklahoma and Texas territories (Condon, as cited in Bluestone, 1973; Sinclair, 1979). Anxious for the political tone of the novel, Zanuck also convinced Steinbeck for the necessity to change the ending from despair — that the pregnant Rosasharn feeds a starving man with her breast milk — to hope — the optimistic we-the-people speech by Ma Joad (Sinclair, 1979).

Notwithstanding the directed criticisms might be right and valid to some extent, the feeling aroused by the film, generally speaking, is true to the spirit of the book. The critical and dramatic episodes in the book, which are at the heart of the narrative, can said to be successfully projected on the screen. The main idea throughout the novel is, in no way, reversed or garbled to direct the viewer into an utterly 
different perception. In the film, I attach importance especially to the consciousness gained by Tom and Ma Joad throughout the experiences lived by the family that lead to grasp themselves as part of the people (we-the-people) and to be determined to join the struggle of the poor and the oppressed. We witness this climactic point in Tom's final speech:

I'll be all around in the dark. I'll be everywhere. Wherever you can look. Wherever there's a fight so hungry people can eat, I'll be there. Wherever there's a cop beating up a guy, I'll be there. I'll be in the way guys yell when they're mad. I'll be in the way kids laugh when they're hungry and they know supper's ready. And when people are eating the stuff they raise, living in the houses they build, I'll be there too. (Ford)

In addition, the images and expressions of poverty and despair are strong enough evidence that the film faithfully attempts to transmit the spirit of the book. As a matter of fact, after seeing the Hollywood preview of the film, Steinbeck reported it as a "hard, straight picture... that looks and feels like a documentary film and ... has a hard, truthful ring" (DeMott, 2000, p.xi) I will go into some details for criticisms that put forth the differences of the film from the book and the points with regard to the visual style in the next two consecutive sections.

\section{Novel into Film: Differences}

It is true that the differences between the novel and the film The Grapes of Wrath, or mutations, are numerous. To state a few, while in the novel, the family is subordinate to the mass of people, and only a part of a larger organism including the land, plants, animals, and weather (Sobchack, 1979), the film focuses on the family, as denoted in the previous section. Moreover, the literal and figurative zoology is totally ignored in the film as pointed out by George Bluestone (1973). We neither see an image nor hear a word related to animals that Steinbeck appealed as metaphors or to depict the environment of the story. Likewise, the interchapters where the analyses with regard to capitalism and working class are made in a highly literary form (Bluestone), and the small episodes that reveal the unfair business practices are dropped entirely in the film (Asheim, as cited in Bluestone). The mutations are not limited to the above-mentioned few examples. However, the adaptation of a novel into film is, first of all, a creative undertaking that requires a selective interpretation (McFarlane, 1996). In every adaptation, the novel is viewed as a raw material, and the filmmaker does not look to the organic novel but to the characters and incidents. The novel is not converted at all but paraphrased; thus, mutation is inevitable where the filmmaker becomes a new author in his own right (Bluestone, 1973). A conversion is not possible without destroying an integral part of the novel (Bluestone, 1973) for "the end products of novel and film represent different aesthetic genera, as different from each other as ballet is from architecture" (Bluestone, 1973, p.5). Aiming to make a film identical to the novel and thus shooting all of the episodes, incidents, and depictions one by one, a method of that kind would produce an extremely long and probably a boring art object for its target audience. Therefore, the differences or divergences are in the very nature of an adaptation process.

On the other hand, the analysis made in the doctoral dissertation by Lester Asheim in 1949 does not confirm the criticisms that point out that the above-mentioned differences between the novel and film versions of The Grapes of Wrath are that important. According to Asheim (as cited in Bluestone, 1973), the ratios of the major sequences to the whole of the narrative are similar in the film and in the parenting novel. The table shows that information:

\begin{tabular}{lcc} 
& \multicolumn{2}{c}{ Per cent of whole } \\
Sequence & Book & Film \\
Oklahoma episodes & 20 & 28 \\
Cross-country episodes & 19 & 22 \\
General commentary & 17 & - \\
Government camp episodes & 15 & 18 \\
Hooverville episodes & 10 & 13 \\
Strike-breaking episodes & 9 & 16 \\
Final episodes & 10 & 3 \\
& ---- & --- \\
& 100 & 100
\end{tabular}


There are many parts of the novel, which are not filmed at all or handled differently in the film, a case which is inherent to an adaptation process. Regarding the shot sequences, thus the end product as the film, one can safely say that - referring to Asheim's analysis - the aim of the creators were to transfer the main idea and pattern of the novel to the audience.

\section{Visual Style}

Vivian Sobchack (1979) argues, speaking of The Grapes of Wrath, visually oriented film criticism has not been employed enough, compared with the literal emphasis of adaptation criticism and cultural criticism. A careful visual analysis of the film, Sobchack notes, puts forth that Ford's main interest similar to the criticisms with regard to content - is not the mankind like Steinbeck but the Joads as a family unit: this choice of Ford is evidenced through two visual elements throughout the film, that is, shot scales and lighting.

Sobchack (1979) observes that, although the relations of the Joad family with the other people, the land, and the political climate are established through the dialogues, they are visually isolated from that larger context. In omitting the wide-open spaces, Ford's choice for the cramped close-up and medium shots in the limited space of a truck or tent serve to disconnect the Joads from larger forces and movements, whereas the larger forces and movements give the novel its epic quality, she argues. The emphasis of the camera is on the faces of Joads, not on the other people they meet (Sobchack). In a similar manner, Andrew Sinclair (1979) observes that Tom Joad is trapped by the cabin of their truck and confined to the inner space. Jim Sanderson (1989) shares the view that very little land is shown throughout the film. Besides, Warren French (as cited in Sobchack, 1979) states that 25 of the 50 scenes in the film are entirely or partly shot either in the truck or within an oppressive interior. In fact, it is known that Ford prefers wide-open spaces: "I like fresh air, the wide open spaces, the mountains, the desert..." (Sinclair, 1979, p.27). A study of the director's western and works of other genres would clearly verify this choice.
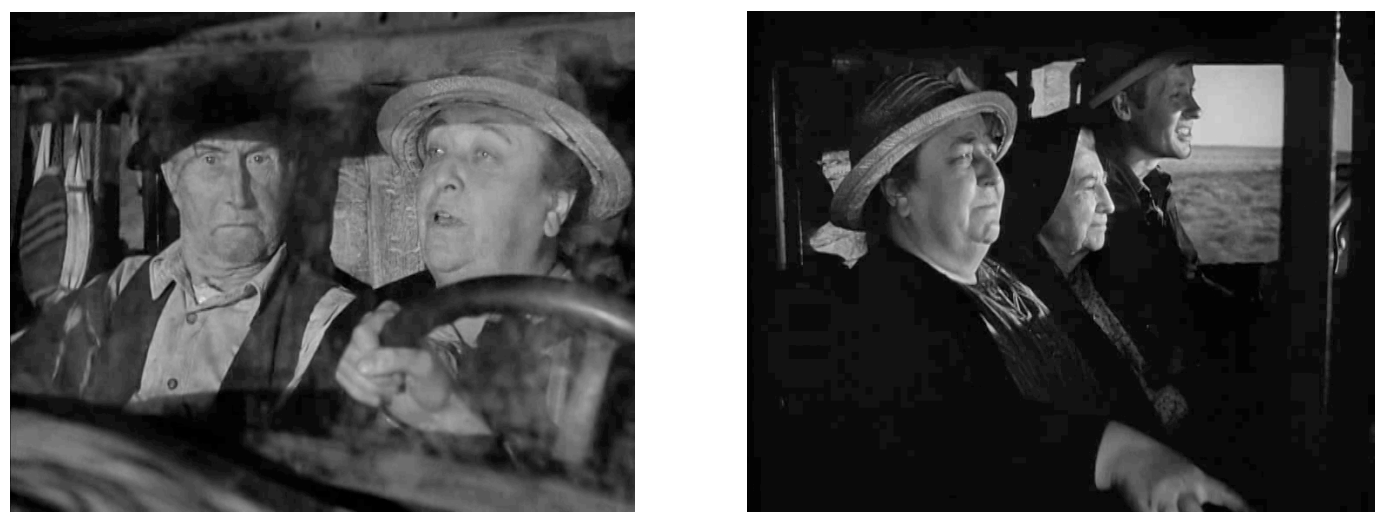

Figure 2: Sample cramped images shot in the truck.

According to Sobchack (1979), the shots that isolate the Joads and those that omit the wide-open spaces serve to "make Joads more important than the problems they face" and to abstract or ignore the Depression, the blowing away land, and the whole world outside the Joads (p.606). Notwithstanding agreeing with the existence of plenty of cramped images in the inner spaces and the scarcity of wideopen spaces in the film, I would argue that Ford's choices should have been urged by the necessities that are forced by the story. Speaking of the adaptation, one should consider that a significant part of the parenting novel is narrated from within the truck that is travelling on the road. What Rose of Sharon (Rosasharn) in the film says to her husband Connie in a close-up shot at the back of the truck provides a justification for all of those criticized shooting choices of Ford: "Seems like we wasn't never doing nothing but moving. I'm tired" (Ford).

The lighting is the second visual element shown as evidence to argue that Ford's main interest is the family. Warren French (as cited in Sobchack, 1979) points out that an important part of the film, 
almost the half, takes part at night or in the dark. The chiaroscuro lighting is claimed by Sobchack (1979) to serve to abstract the Joads through obscuring the connection between the various objects in a frame and to turn our attention to the family. On the other hand, according to French (as cited in Sobchack, 1979), the potential of the story that is capable of producing a social protest on the screen is converted into an artful product by Ford's visual choices. The result of those choices has also been called as "radical in style" (Sinclair, 1979, p.98) and "seldom has a Ford picture been a world so unreal" (Gallagher, 1986, p.180).
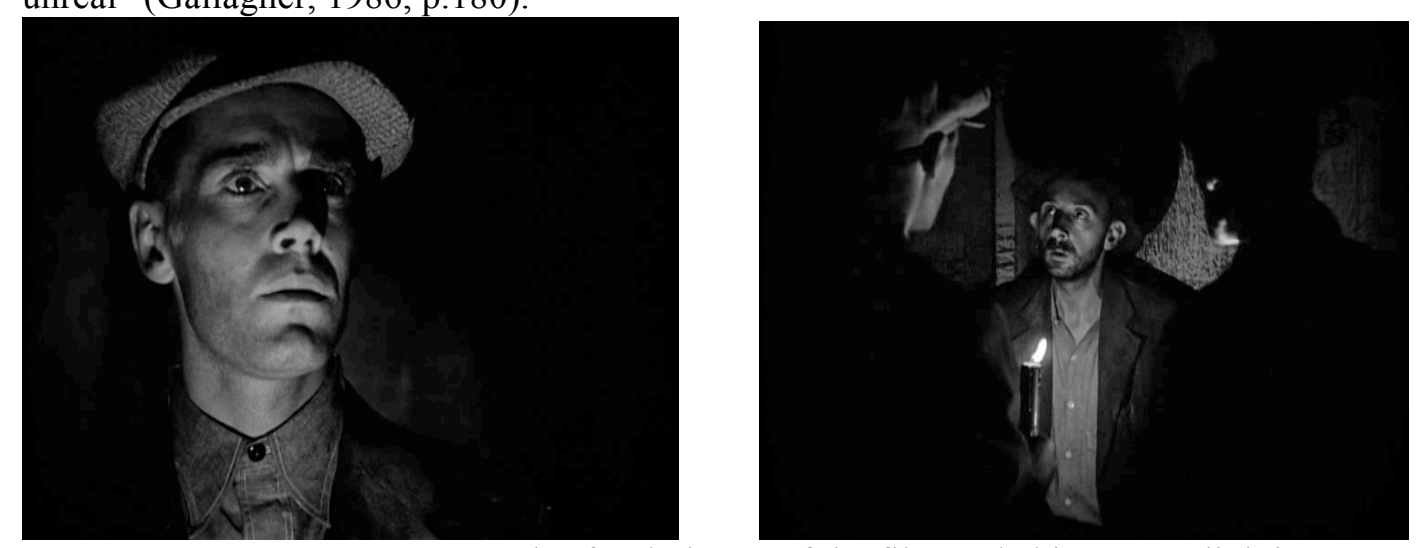

Figure 3: Samples for darkness of the film and chiaroscuro lighting.

For those criticisms of darkness of the film, I would uphold Ford again by a similar argument that I deployed against close-up criticisms: a very important part of the parenting novel takes place at night, and one should ask why the director of the film should change that fact.

\section{Conclusion}

Compared with the parenting novel, the film The Grapes of Wrath has repeatedly been criticized for its conservative tone, not only in terms of content but also in its visual style that is claimed to focus on the Joad family and isolate them from the larger mass of people. John Ford, as the director of the film, took his share of criticisms as well. On the other hand, the film could not escape the criticisms from the conservative circles.

Despite all of the aforementioned criticisms directed at the film - which I would partly agree, one cannot claim that Ford ruined a good quality novel. On the contrary, it can be contended without any doubt that he bestowed a masterpiece to film history. In this sense, I would share the viewpoint of Lindsay Anderson (1981) who stated the following:

For it is the epic style with which Ford developed the narrative, and his passionate, abrasive, tender human commitment, that gives the film its greatness. It is a film of monumental stature, in which the small, infinitely significant details of human suffering and aspiration were yet never lost. (pp.68-70).

It is this film that located Ford among the grand seigneurs of Hollywood (Anderson, 1981). Evaluated in the historical conditions of its period and compared with the other films of Hollywood in the past and today, The Grapes of Wrath is not a conservative film at all. Moreover, I argue, without any reservation, that it is quite a brave film both as an attempt and as the output, for exposing the main and side effects of a depression that is inevitable in a capitalist society. If there will be any, criticisms related to the conservativeness of the content should go to the producing company and the artistic approbation to the director.

Finally, when it comes to our time, considering the current economic crisis that has pervaded and diffused into many societies in recent years, the cinema audience is already waiting for new Fords and up-to-date The Grapes of Wraths that narrate today's working class and the unemployed masses. 


\section{REFERENCES}

Anderson, L. (1981). About John Ford... London, England: Plexus.

Asheim, L. (1949). From book to film (Unpublished doctoral thesis). University of Chicago, United States of America.

Bluestone, G. (1973). Novels into film (sixth printing). Berkeley, United States of America: University of California Press.

Bogdanovich, P. (1978). John Ford. Berkeley, United States of America: University of California Press.

Cassano, G. (2008). Radical critique and progressive traditionalism in John Ford's The Grapes of Wrath 1. Critical Sociology 34(1), 99-116. doi: 10.1177/0896920507084627.

Condon, F. (1940, January 27). The grapes of raps. Collier's.

DeMott, Robert. (2000). Introduction. In J. Steinbeck, The grapes of wrath (pp. ix-xl). London, England: Penguin.

Ford, J. (Director). (1940). The grapes of wrath [Motion picture]. United States of America: 20 ${ }^{\text {th }}$ Century Fox.

French, W. (1973). Filmguide to The Grapes of Wrath. Bloomington, United States of America: Indiana Univ. Press.

Gallagher, T. (1986). John Ford: The man and his films. Berkeley, United States of America: University of California Press.

McBride, J. (2001). Searching for John Ford: A life. New York, United States of America: St. Martin's Griffin Press.

McFarlane, B. (1996). Novel to film: An introduction to the theory of adaptation. Oxford, England: Clarendon Press.

Sanderson, J. (1989). American romanticism in John Ford's The Grapes of Wrath. Literature/Film Quarterly 17(4), 231-244.

Sarris, A. (1976). The John Ford movie mystery. London, England: Secker \& Warburg.

Sinclair, A. (1979). John Ford. New York, United States of America: The Dial Press/James Wade.

Sobchack, V. C. (1979). The grapes of wrath (1940): Thematic emphasis through visual style. American Quarterly 31(5): 596-615. Special Issue: Film and American Studies (Winter).

Steinbeck, J. (2000). The grapes of wrath. London, England: Penguin.

Tavernier, B. (1967, March). John Ford à Paris. Positif 82. 